\title{
Zmiany najnowszych Wytycznych Leczenia i Prewencji Astmy - GINA 2014. Na co powinniśmy zwrócić uwagę?
}

\author{
Changes in the newest recommendations on Asthma Management and Prevention \\ — GINA Report 2014. What should we pay attention to? \\ Praca nie była finansowana
}

Pneumonol. Alergol. Pol. 2014; 82: 393-401

W maju 2014 roku, w Światowym Dniu Astmy opublikowane zostały znowelizowane wytyczne leczenia i prewencji astmy, opracowane przez ekspertów Światowej Inicjatywy na Rzecz Astmy (GINA, the Global Initiative for Asthma) [1]. Pierwsze wytyczne GINA ukazały się ponad 20 lat temu, w 1993 roku. Od tego czasu były wielokrotnie aktualizowane na podstawie nowych wyników badań. Obecna nowelizacja jest nie tylko uzupełnieniem dotychczasowej wiedzy o astmie, ale zawiera także istotne zmiany dotyczące rozumienia istoty samej choroby (jej heterogenności etiologicznej i klinicznej) oraz wytyczne dotyczące zarządzania związanym $\mathrm{z}$ nią ryzykiem. Podejmuje też nowe kwestie jak współistnienie astmy i przewlekłej obturacyjnej choroby płuc oraz zawiera wytyczne dotyczące diagnostyki i leczenia astmy u małych dzieci. Całość opracowania zawarto na 132 stronach, w 8 rozdziałach podzielonych na trzy sekcje: pierwszą dotyczącą astmy u dorosłych, młodzieży i dzieci powyżej 6. roku życia, drugą - astmy u dzieci w wieku lat 5 i młodszych, i trzecią - poświęconą wdrożeniu wytycznych w podstawowej opiece zdrowotnej. Rekomendacje zostały uporządkowane, dodano wiele przydatnych algorytmów i rycin, usunięto mniej istotne fragmenty tekstu.
Wśród kluczowych merytorycznych zmian w dokumencie należy wymienić przede wszystkim nową definicję astmy (tab. 1), w której podkreślono jej heterogenną naturę. Definicję uproszczono, usuwając z niej szczegółowe elementy patomorfologiczne. $\mathrm{W}$ obecnym brzemieniu ma bardziej praktyczny charakter.

Eksperci podają przykłady fenotypów astmy (ryc. 1) i podkreślają, że poza przypadkami ciężkiej astmy alergicznej, w której jest dostępne odpowiednie do fenotypu leczenie biologiczne, nie stwierdzono związku między pewnymi specyficznymi patomechanizmami a przebiegiem klinicznym czy odpowiedzią na leczenie.

Eksperci kładą nacisk na konieczność potwierdzenia rozpoznania astmy za pomocą obiek-

Tabela. 1. Definicja astmy z raportu GINA 2014 [1]

Table 1. Definition of asthma from GINA Report 2014 [1]

Astma to heterogenna choroba, zwykle związana z przewlekłym zapaleniem dróg oddechowych, zdefiniowana przez zespół objawów ze strony układu oddechowego jak świsty, duszności, ucisk w klatce piersiowej i kaszel, zmieniających się w czasie i o różnym nasileniu, którym towarzyszy zmienna obturacja dróg oddechowych

Adres do korespondencji: dr hab. n. med. Izabela Kupryś-Lipińska, Klinika Chorób Wewnętrznych, Astmy i Alergii Uniwersytetu Medycznego w Łodzi, ul. Kopcińskiego 22, 90-153 Łódź, e-mail: izabela.kuprys-lipinska@umed.lodz.pl

DOI: 10.5603/PiAP.2014.0051

Praca wpłynęła do Redakcji: 18.06.2014 r.

Copyright (C) 2014 PTChP

ISSN 0867-7077 


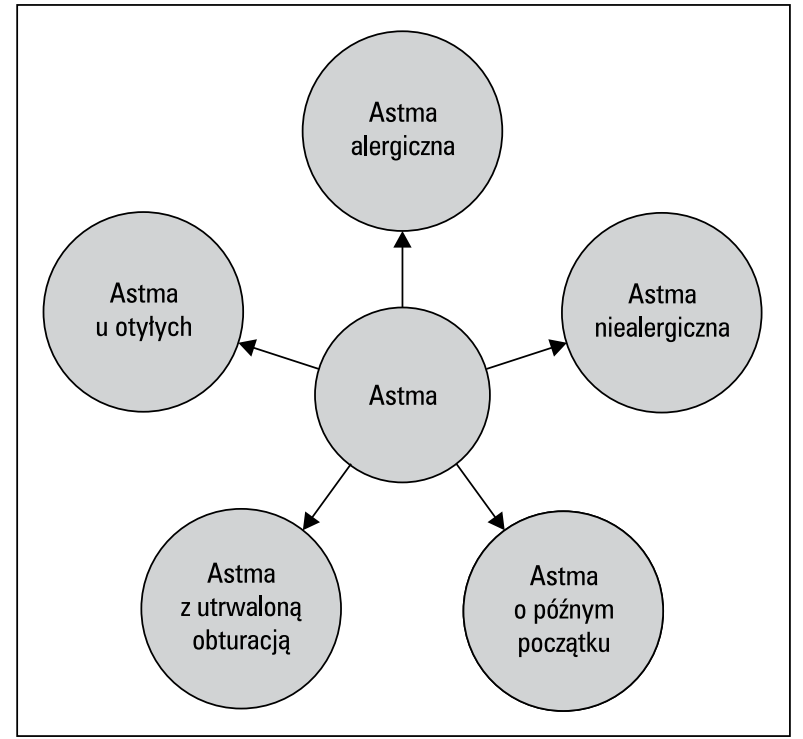

Rycina 1. Przykłady fenotypów astmy według ekspertów GINA [1]

Figure 1. Examples of asthma phenotypes according to GINA experts [1]

tywnych testów w celu wdrożenia odpowiedniego leczenia, gdy jest ono niezbędne, lub odstąpienie od niepotrzebnej terapii. Rozpoznanie astmy stawia się na podstawie charakterystycznych objawów (ich zmienność, czynniki prowokujące, ustępowanie samoistne lub pod wpływem leków) i potwierdza testem odwracalności obturacji (próba rozkurczowa) lub innymi badaniami czynnościowymi (testy prowokacyjne swoiste lub nieswoiste, zmienność PEF [peak expiratory flow], poprawa czynności płuc po leczeniu). Eksperci podkreślają, że w astmie zwykle występuje nadreaktywność dróg oddechowych i zapalenie, ale ich stwierdzenie nie jest równoznaczne z rozpoznaniem astmy, bo mogą występować także w innych jednostkach chorobowych. Ponadto, u osób leczonych lekami przeciwzapalnymi stany te moga ustępować. Diagnostykę astmy, jeśli to możliwe, powinno przeprowadzić się przed włączeniem leków kontrolujących, ale w sytuacjach naglących lub kiedy nie można przeprowadzić diagnostyki, możliwe jest zastosowanie empirycznego leczenia wziewnymi glikokortykosteroidami (ICS, inhaled corticosteroids) i szybko działającymi beta-mimetykami i obserwacja odpowiedzi na leczenie.

W dokumencie znajdują się rekomendacje dotyczące diagnostyki w szczególnych grupach chorych, na przykład z izolowanym kaszlem, w astmie zawodowej i zależnej od czynników zawodowych, u sportowców i kobiet ciężarnych u osób otyłych, w podeszłym wieku i już w trakcie leczenia.

Kolejną nowością jest zarządzanie ryzykiem astmy, którego cel stanowi minimalizacja ryzyka

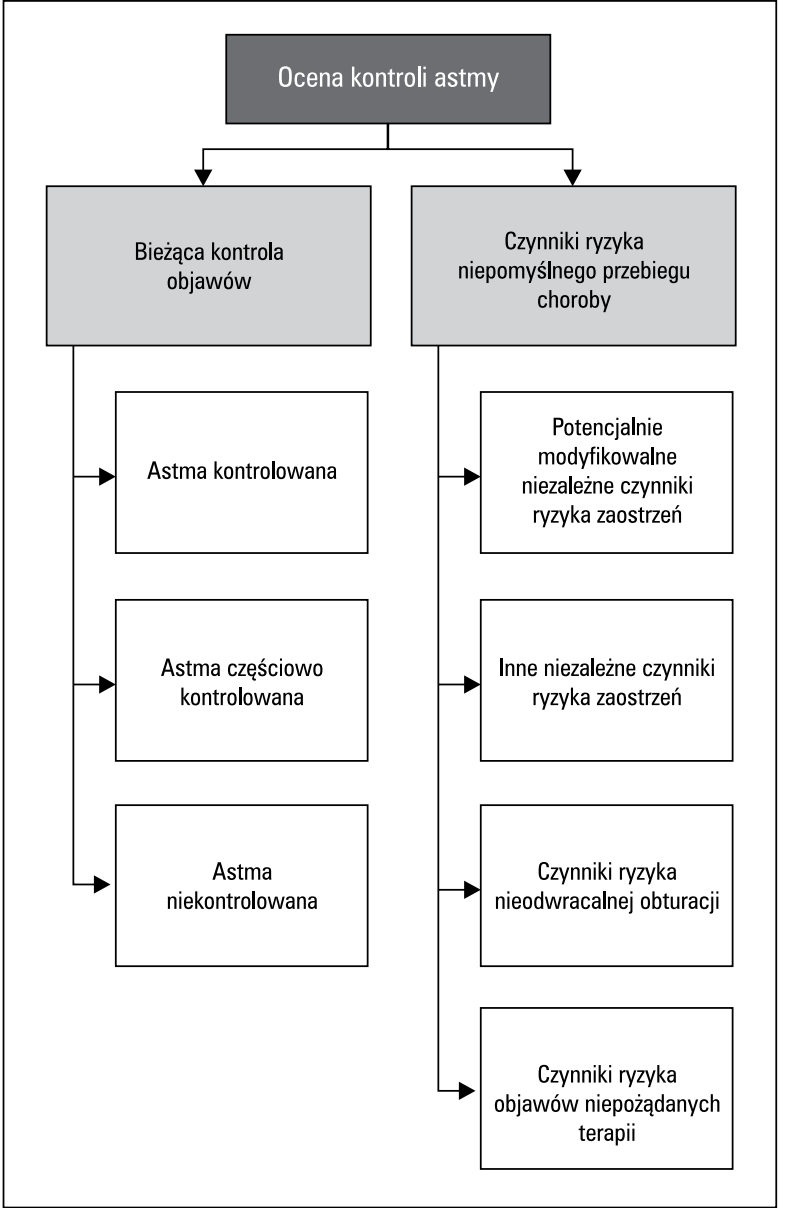

Rycina 2. Ocena kontroli astmy według kryteriów GINA 2014 [1]

Figure 2. Assessment of asthma control according to GINA 2014 criteria [1]

przyszłych zaostrzeń astmy, inwalidztwa oddechowego i powikłań jatrogennych. W ocenie pacjenta utrzymano koncepcję dwóch domen bieżącej kontroli i przyszłego ryzyka niepomyślnych zdarzeń (ryc. 2). Na bieżącą kontrolę mają wpływ aktualne objawy astmy, zapotrzebowanie na lek ratunkowy, czynność płuc i wpływ choroby na codzienną aktywność chorego. Podział na astmę kontrolowaną, częściowo kontrolowaną i niekontrolowaną nie zmienił się w porównaniu $\mathrm{z}$ poprzednimi raportami. Znacznie rozbudowano za to ocenę przyszłego ryzyka, wyodrębniając dla każdego z ocenianych problemów indywidualne czynniki zwiększające ryzyko wystąpienia niekorzystnego zdarzenia zdrowotnego, kładąc największy nacisk na redukcję ryzyka zaostrzeń astmy. Czynniki wpływające na przyszłe ryzyko zaostrzeń podzielono na potencjalnie modyfikowalne (brak bieżącej kontroli astmy, zwiększone zapotrzebowanie na leki ratunkowe, nieadekwatne stosowanie ICS, czy to z powodu za niskiej ich dawki, czy złej techniki inhalacji lub niestosowa- 
nia się do zaleceń lekarskich, $\mathrm{FEV}_{1}<60 \%$ w.n., problemy psychologiczne i socjalne, ekspozycja na dym tytoniowy, uczulające alergeny, otyłość, alergiczny nieżyt nosa, alergia pokarmowa, eozynofilia układu oddechowego lub systemowa, ciąża) i inne (zaostrzenie zagrażające życiu [intubacja/OIOM] w przeszłości, ciężkie zaostrzenie w okresie ostatnich 12 miesięcy). Eksperci podkreślają, że wystąpienie choć jednego z tych czynników, nawet przy bieżącej dobrej kontroli objawów, zwiększa ryzyko przyszłych zaostrzeń. Ma to swoje implikacje terapeutyczne.

Do monitorowania przebiegu astmy eksperci zalecają wykonywanie badania spirometrycznego, jako przydatnego narzędzia w ocenie przyszłego ryzyka, podkreślając, że wynik spirometrii może jednak nie mieć związku z bieżącą kontrolą astmy. Przy kolejnych pomiarach w trakcie prowadzenia leczenia nie ma konieczności odstawiania leków, które pacjent przyjmuje na stałe i doraźnie, należy zachować tylko takie same warunki badania.

Eksperci podkreślają różnicę miedzy oceną kontroli astmy i stopniem ciężkości, zalecając ocenę ciężkości retrospektywnie na podstawie stopnia intensywności leczenia koniecznego do zapewnienia kontroli objawów i zaostrzeń. Podkreślają również, że zła kontrola bieżących objawów astmy i zaostrzeń może mieć różne przyczyny i wymagać innego postępowania terapeutycznego.

Wytyczne dotyczące leczenia astmy są zmienione nieznaczne (tab. 2), choć w obecnym do- kumencie chyba najwyraźniej widać, że leczenie farmakologiczne jest tylko jednym z elementów opieki nad pacjentem, obok nie mniej ważnej edukacji, roli samego chorego w procesie terapeutycznym i realizowania zaleceń postępowania niefarmakologicznego. Wziewne glikokortykosteroidy pozostają najważniejszym lekiem kontrolującym (zmniejszają objawy, ryzyko zaostrzeń, hospitalizacji i zgonu z powodu astmy), a intensyfikacja leczenia pozostaje oparta na 5 stopniach. Warto zwrócić uwagę na fakt, że po raz pierwszy w rekomendacjach GINA pojawiło się zalecenie stosowania w leczeniu podtrzymującym i doraźnym połączenia beklometazonu $\mathrm{z}$ formoterolem w jednym inhalatorze, obok wcześniej rekomendowanej kombinacji budezonidu $\mathrm{z}$ formoterolem, u osób wymagających na co dzień niskich dawek ICS z LABA (long acting beta2-agonist). Pojawiły się też szczegółowe zalecenia dla lekarzy rozpoczynających terapię u chorych z nowo rozpoznaną astmą. Nowością jest odrębne zestawienie dawek równoważnych ICS dla dzieci między 6. a 11. rokiem życia. Jest to istotne ze względu na ocenę ryzyka objawów niepożądanych w tej wrażliwej na działanie ICS grupie wiekowej. Eksperci zwracają uwagę na konieczność monitorowania chorych i utrzymują stopniową intensyfikację leczenia w przypadku braku kontroli, podkreślając, że pełnych rezultatów można się spodziewać po 3, 4 miesiącach leczenia. W przypadku braku zadowalającej poprawy rekomendują w pierwszej kolejności, przed zwiększeniem dawek leków,

Tabela 2. Stopnie intensywności terapii według raportu GINA 2014 [1]

Table 2. Stepwise approach in asthma therapy according to GINA recommendation [1]

\begin{tabular}{|c|c|c|c|c|}
\hline \multirow{2}{*}{$\begin{array}{c}\text { Stopień } \\
\text { terapii }\end{array}$} & \multicolumn{2}{|c|}{ Terapia kontrolująca } & \multirow[t]{2}{*}{ Leki ratunkowe } & \multirow[t]{2}{*}{ Inne zalecane metody interwencji } \\
\hline & preferowane & inne opcje & & \\
\hline 1 & Bez terapii & Niska dawka ICS & Doraźnie SABA & \multirow{5}{*}{$\begin{array}{l}\text { Edukacja } \\
\text { Samokontrola } \\
\text { Indywidualny plan terapii } \\
\text { Niefarmakologiczne interwencje } \\
\text { Terapia chorób wspóttowarzyszących i mo- } \\
\text { dyfikacja czynników ryzyka } \\
\text { Przed intensyfikacją: } \\
\text { • kontrola stosowania się do zaleceń } \\
\text { • kontrola techniki inhalacji } \\
\text { Redukcja terapii jeśli: } \\
\text { • dobra kontrola objawów przez } 3 \text { miesiące } \\
\text { - niskie ryzyko zaostrzeń }\end{array}$} \\
\hline 2 & Niska dawka ICS & $\begin{array}{l}\text { LTRA lub niska dawka } \\
\text { teofiliny }\end{array}$ & & \\
\hline 3 & Niska dawka ICS + LABA & $\begin{array}{c}\text { Średnia/wysoka dawka } \\
\text { ICS } \\
\text { Niska dawka } \\
\text { ICS+LTRA }\end{array}$ & \multirow[t]{3}{*}{$\begin{array}{l}\text { Doraźnie SABA lub po- } \\
\text { tączenie niskiej dawki } \\
\text { ICS+FORM* }\end{array}$} & \\
\hline 4 & $\begin{array}{c}\text { Średnia/wysoka dawka } \\
\text { ICS + LABA }\end{array}$ & $\begin{array}{l}\text { Średnia/wysoka dawka } \\
\text { ICS + LTRA }\end{array}$ & & \\
\hline 5 & $\begin{array}{c}\text { Dodatkowe leczenie dodane } \\
\text { do leczenia 4. stopnia } \\
\text { np. anty-lgE, } \\
\text { Konsultacja specjalistyczna }\end{array}$ & Niska dawka OCS & & \\
\hline
\end{tabular}

ICS (inhaled corticosteroids) — wziewne glikokortykosteroidy; LTRA (leukotriene receptor antagonists) — antagoniści receptora leukotrienów; SABA (short acting beta2-agonists) — krótkodziałające beta2-mimetyki; FORM (formoterol) — formoterol; 0CS (oral corticosteroids) — doustne glikokortykosteroidy *u pacjentów stosujących długotrwale niską dawkę budezonidu z formoterolem lub beklometazonu z formoterolem 
sprawdzenie techniki inhalacji leków i compliance. Natomiast po osiągnięciu kontroli po 3 miesiącach zalecają stopniową redukcję terapii w celu ustalenia najniższych skutecznych dawek leków, by zminimalizować ryzyko polekowych objawów niepożądanych. Zwracają też uwagę na istotną rolę samego chorego w procesie terapeutycznym i konieczność identyfikacji jego potrzeb przy wyborze leczenia oraz na istotną umiejętności komunikowania się z chorym w optymalizacji efektów terapii, zwiększenia satysfakcji chorego, jak i poprawy wykorzystania zasobów systemu ochrony zdrowia.

U pacjentów z ciężką astmą, którzy nie uzyskują kontroli choroby na 4 . stopniu intensywności leczenia obok terapii anty-IgE (zalecanej dla chorych na umiarkowaną i ciężką postać astmy alergicznej) pojawia się rekomendacja dla endoskopowej termoplastyki oskrzeli (z komentarzem, że jest to zalecenie oparte na wynikach badań w wyselekcjonowanej grupie pacjentów a efekt długoterminowy jest jeszcze nie w pełni poznany), oraz optymalizacja dawki ICS na podstawie wyniku cytologicznego plwociny.

Eksperci zwracają szczególną uwagę na grupę chorych doświadczających ciężkich zaostrzeń astmy, podkreślając, że występują one nawet u osób z bieżącą dobrą kontrolą lub stosujących maksymalną rekomendowaną terapię. Zalecają optymalizację, a nie maksymalizację leczenia i identyfikację czynników ryzyka, jak również zwracają uwagę, że nie wszystkie czynniki ryzyka są modyfikowalne i dlatego nie wymagają intensyfikacji farmakoterapii.

Ciekawy jest fragment zaleceń poświęcony postępowaniu niefarmakologicznemu, w tym ocena roli i efektywności niektórych interwencji (tab. 3).

Dużo uwagi w raporcie poświęcono identyfikacji chorych niestosujących się do zaleceń lekarskich i sposobom zmiany takiej sytuacji między innymi przez włączenie w proces decyzyjny samego chorego, upraszczanie schematów leczenia i kontrolę wypełniania zaleceń. Eksperci przypominają też o elementach edukacji i roli oraz korzyściach ze stosowania indywidualnego planu leczenia.

Eksperci zwracają też uwagę na fakt, że u osób chorujących na astmę, szczególnie na jej postać ciężką lub trudną do leczenia, mogą występować choroby współistniejące, które odpowiedzialne są za niektóre objawy ze strony układu oddechowego, mają istotny wpływ na jakość życia, ale też mogą pogarszać kontrolę astmy (ryc. 3). Do najczęstszych problemów zdrowotnych występujących u chorych na astmę należą: przewlekłe zapalenie błony śluzowej nosa i zatok przynosowych, otyłość, choroba refluksowa przełyku, zaburzenia psychiczne. Chorzy $\mathrm{z}$ ciężką lub trudną do leczenia astmą powinni być konsultowani przez specjalistów w celu weryfikacji rozpoznania, ustalenia właściwego leczenia astmy i chorób współtowarzyszących.

Uzupełniono i uporządkowano też grupy chorych wymagające szczególnej uwagi i postępowania diagnostyczno-terapeutycznego, między innymi o młodzież (tab. 4).

Nowością w dokumencie jest rozróżnienie przez ekspertów astmy trudnej do leczenia od opornej na leczenie i zdefiniowanie astmy ciężkiej (tab. 5). W raporcie ekspertów GINA astma trudna do leczenia to taka, w której nie można osiągnąć kontroli choroby z powodu dodatkowych niezależnych od choroby czynników jak choroby współwystępujące, niestosowanie się chorych do zaleceń, ekspozycja na alergeny. Astma oporna na leczenie rozpoznawana jest u chorych, u których nie udaje się osiągnąć kontroli objawów lub zaostrzeń mimo stosowania wysokich dawek ICS w połączeniu z LABA (i/lub doustnych glikokorytosteroidów) oraz leczenia chorób współtowarzyszących, jak również u osób, u których kontrola choroby pogarsza się przy próbie redukcji (step down) takiego leczenia. Do grupy z astmą ciężką eksperci GINA za konsensusem European Respiratory Society/American Thoracic Society (ERS/ ATS) z 2014 roku [2] zaliczyli astmę oporną na leczenie i taką, w której odpowiedź na leczenie chorób współtowarzyszących nie jest pełna. Eksperci podkreślają, że pacjenci chorujący na ciężką astmę są heterogenną grupą, w której można wyróżnić kilka charakterystycznych populacji: z wczesnym początkiem ciężkiej astmy alergicznej; astmę nieatopową z późnym początkiem steroidozależną z utrwaloną obturacją dróg oddechowych; starsze otyłe kobiety z późnym początkiem astmy. Odkryto tylko kilka swoistych biologicznych dróg reakcji, które docelowo mogą stać się miejscem interwencji terapeutycznej — jak anty-IgE w ciężkiej astmie alergicznej, ale prowadzone są dalsze intensywne badania w tym kierunku. Pacjenci z trudną i ciężką astmą powinni być objęci opieką specjalistyczną. Eksperci zwracają uwagę, że koniecznym elementem w opiece nad chorymi z trudną i ciężką astmą jest potwierdzenie rozpoznania, przytaczając dane statystyczne, że 12-50\% ma postawioną niewłaściwą diagnozę. W terapii zaleca się kompromis między możliwością kontroli choroby a objawami ubocznymi prowadzonego leczenia. 
Tabela 3. Niefarmakologiczne interwencje w astmie i ich efektywność na podstawie rekomendacji GINA 2014 [1]

Table 3. Non-pharmacological interventions of asthma and its effectiveness based on the recommendation of the GINA 2014 [1]

\begin{tabular}{|c|c|}
\hline Typ interwencji & Efektywność poszczególnych interwencji \\
\hline Walka z nałogiem palenia tytoniu & Należy zachęcać i wspierać chorych na astmę w walce z nałogiem \\
\hline $\begin{array}{l}\text { Unikanie biernego narażenia } \\
\text { na dym tytoniowy }\end{array}$ & $\begin{array}{l}\text { Chorzy na astmę powinni unikać ekspozycji na dym tytoniowy. W szczególności należy uwrażliwiać } \\
\text { rodziców i opiekunów dzieci chorych na astmę, by nie palili i nie pozwalali na palenie w pokojach, gdzie } \\
\text { przebywają dzieci }\end{array}$ \\
\hline $\begin{array}{l}\text { Unikanie narażanie na czynniki } \\
\text { zawodowe }\end{array}$ & $\begin{array}{l}\text { Konieczność diagnostyki w grupie aktywnej zawodowo z astmą o późnym początku i eliminacji naraże- } \\
\text { nia w przypadkach potwierdzenia uczulenia na czynniki zawodowe }\end{array}$ \\
\hline $\begin{array}{l}\text { Unikanie leków prowokujących } \\
\text { objawy astmy }\end{array}$ & $\begin{array}{l}\text { Należy pytać o stosowane leki i ich wpływ na objawy astmy, niesteroidowe leki przeciwzapalne nie są } \\
\text { generalnie przeciwwskazane w astmie, jeśli nie pogarszają przebiegu choroby, podobnie jak selektywni } \\
\text { beta-antagoniści stosowani w chorobie niedokrwiennej serca i leki okulistyczne zawierające beta- } \\
\text {-antagonistów, ale włączane ich powinno być poprzedzone szczegółowym wywiadem i odbywać się } \\
\text { pod nadzorem }\end{array}$ \\
\hline $\begin{array}{l}\text { Zmniejszanie ekspozycji } \\
\text { na alergeny wewnątrzdomowe }\end{array}$ & Drogie techniki eliminacji, a efekt niepewny \\
\hline Regularna aktywność fizyczna & $\begin{array}{l}\text { Korzystny wpływ na ogólny stan zdrowia, należy stosować profilaktykę indukowanego wysiłkiem } \\
\text { skurczu oskrzeli tam, gdzie to konieczne }\end{array}$ \\
\hline Trening techniki oddychania & Szkolenie może być korzystne jako dodatkowa strategia do, ale nie zamiast, farmakoterapii \\
\hline Zdrowa dieta & Bogata w warzywa i owoce — ogólnie korzystna dla zdrowia \\
\hline Redukcja masy ciała & $\begin{array}{l}\text { Korzystna jest normalizacja masy ciała, dlatego powinna być jednym z elementów leczenia astmy } \\
\text { u otyłych chorych }\end{array}$ \\
\hline $\begin{array}{l}\text { Unikanie zanieczyszczeń } \\
\text { powietrza w domu }\end{array}$ & $\begin{array}{l}\text { Korzystne jest unikanie procesów technologicznych związanych z zanieczyszczeniami powietrza } \\
\text { wewnątrz domu i konieczna skuteczna wentylacja pomieszczeń }\end{array}$ \\
\hline Szczepienia ochronne & $\begin{array}{l}\text { Zaleca się szczepienia przeciwko grypie u pacjentów z umiarkowanym i ciężkim stopniem astmy } \\
\text { i przeciwko pneumokokom u dzieci i osób starszych }\end{array}$ \\
\hline $\begin{array}{l}\text { Sposoby radzenia sobie } \\
\text { ze stresem }\end{array}$ & $\begin{array}{l}\text { W grupie osób, u których emocje prowokują objawy astmy, konieczna identyfikacja strategii radzenia } \\
\text { sobie ze stresem, korzystne terapie relaksacyjne i technika prawidłowego oddychania } \\
\text { Wskazana ocena chorych pod kątem objawów nerwicy i depresji }\end{array}$ \\
\hline Swoista immunoterapia & $\begin{array}{l}\text { Korzystna u osób uczulonych, ale czasochłonna i kosztochłonna, należy oszacować indywidualnie korzy- } \\
\text { ści i ryzyko }\end{array}$ \\
\hline Termoplastyka oskrzelowa & Korzystna w ograniczonych grupach chorych, ograniczony dostęp do procedury \\
\hline $\begin{array}{l}\text { Unikanie zanieczyszczeń } \\
\text { powietrza atmosferycznego }\end{array}$ & $\begin{array}{l}\text { W przypadku dobrej kontroli nie zaleca się specjalnych warunków bytowych, ale w niekorzystnych } \\
\text { warunkach atmosferycznych (zanieczyszczenia, zimne powietrze, niska jego wilgotność) nie zaleca się } \\
\text { aktywności fizycznej na świeżym powietrzu, korzystne wówczas jest pozostanie w kontrolowanym } \\
\text { środowisku domowym, a w czasie infekcji wirusowych należy unikać narażenia na zanieczyszczenia } \\
\text { powietrza }\end{array}$ \\
\hline Ograniczenia dietetyczne & Korzystne tylko w grupach ze zdiagnozowaną alergią pokarmową \\
\hline
\end{tabular}

Definicja zaostrzenia astmy została w niewielkim stopniu zmodyfikowana przez dodanie informacji o konieczności modyfikacji leczenia (tab. 6).

Zaostrzenia mogą pojawić się u chorego leczonego z powodu astmy, ale też mogą być pierwszym objawem astmy. Zwykle są związane z ekspozycją na znane czynniki prowokujące lub z występowaniem znanych czynników ryzyka (np. non-compliance). Ciężkie zaostrzenia mogą wystąpić również w łagodnej i dobrze kontrolowanej astmie. Identyfikacja czynników ryzyka, edukacja pacjenta oraz wczesna interwencja medyczna są kluczowe w zapobieganiu i opanowywaniu zaostrzeń, które potencjalnie zagrażają życiu. Pomocny jest indywidualny plan leczenia.
Eksperci przygotowali dla chorych zalecenia dotyczące samodzielnej modyfikacji leczenia w zależności od ciężkości zaostrzenia i stosowanego wcześniej leczenia. Osobne zalecenia przygotowano dla lekarzy podstawowej opieki zdrowotnej i oddziałów ratunkowych. Eksperci zwracają uwagę na problemy terminologii: brak zrozumienia przez pacjentów terminu „zaostrzenie”, wieloznaczność stosowanych określeń takich jak ,atak” i „epizod”, i proponują wprowadzenie terminu wybuch astmy (flare-up) jako najlepiej i najprościej oddającego naturę zaostrzeń, również w przypadkach kiedy chorzy na co dzień nie doświadczają objawów choroby. Według ekspertów intensyfikacja leczenia przez stosowanie od 7 do 
14 dni wysokich dawek ICS tj. od 500 do $1600 \mu \mathrm{g} / \mathrm{d}$. w przeliczeniu na BDP-HFA (hydrofluoroalkane-inhaled beclomethasone) jest równoważna z krótkim kursem doustnych glikokortykosteroidów.

Zupełną nowością w raporcie jest dodanie rozdziału poświęconego współistnieniu astmy

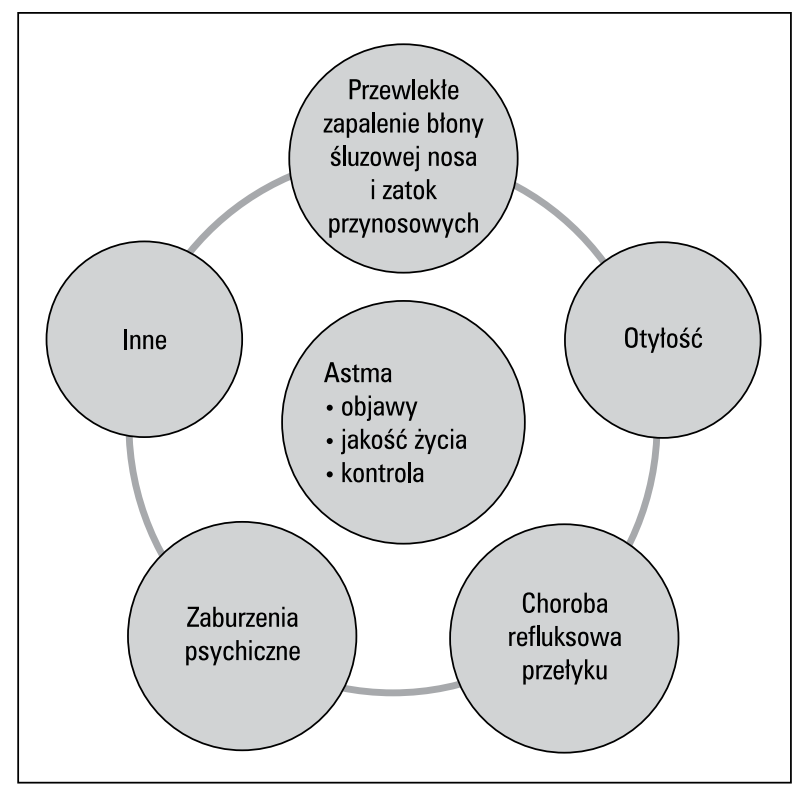

Rycina 3. Wpływ chorób wspóttowarzyszących na przebieg astmy [1]

Figure 3. Effect of concomitant diseases on the course of asthma [1] i przewlekłej obturacyjnej choroby płuc, czyli zespołowi nakładania (ACOS, asthma-COPD overlap symdrome), przygotowanego wspólnie z ekspertami Global Initiative For Chronic Obstructive Lung Disease (GOLD). Rozdział ten zawiera informacje przydatne w rozpoznaniu ACOS, różnicowaniu go z astmą i przewlekłą obturacyjną chorobą płuc (POChP) oraz rekomendacje

\section{Tabela 5. Definicje astmy trudnej do leczenia, opornej na leczenie i ciężkiej według raportu GINA 2014 [1]}

Table 5. Definitions of difficult-to-treat asthma, refractory asthma and severe asthma [1]

\begin{abstract}
Astma trudna do leczenia to taka, w której nie można osiągnąć kontroli choroby z powodu dodatkowych niezależnych od choroby czynników jak choroby współwystępujące, niestosowanie się chorych do zaleceń, ekspozycja na alergeny
\end{abstract}

Astma oporna na leczenie rozpoznawana jest u chorych z potwierdzeniem rozpoznania astmy, u których nie udaje się osiągnąć kontroli objawów lub zaostrzeń mimo stosowania wysokich dawek ICS w połączeniu z LABA (i/lub doustnych glikokortykosteroidów) oraz leczenia chorób wspóttowarzyszących, jak również u osób, u których kontrola choroby pogarsza się przy próbie redukcji (step down) takiego leczenia

Do astmy ciężkiej zalicza się astmę oporną na leczenie i taką, w której odpowiedź na leczenie chorób wspóttowarzyszących nie jest pełna

ICS (inhaled corticosteroids) - wziewne glikokortykosteroidy; LABA (long acting beta2-agonists) — długodziałające beta2-mimetyki

\section{Tabela 4. Wyróżnione przez ekspertów GINA podgrupy chorych na astmę [1]}

Table 4. Special population of asthma patients distinguished by the GINA experts [1]

\begin{tabular}{|c|c|}
\hline Podgrupy chorych na astmę & Kluczowe problemy \\
\hline Młodzież & $\begin{array}{l}\text { Zmiany fizyczne, emocjonalne, poznawcze, społeczne mające wpływ na objawy, zachowanie, } \\
\text { w tym palenie tytoniu, radzenie sobie z chorobą, stosowanie się do zaleceń itp. }\end{array}$ \\
\hline Kobiety ciężarne & $\begin{array}{l}\text { Problem obawy kobiet przed działaniem niepożądanym na płód leków i zaprzestanie z tego powodu } \\
\text { leczenia oraz ryzyko powikłań spowodowanych zaostrzeniami przy wysokim bezpieczeństwie leków } \\
\text { przeciwastmatycznych }\end{array}$ \\
\hline Osoby starsze & $\begin{array}{l}\text { Liczne choroby wspótistniejące, słaba percepcja objawów utraty kontroli astmy, gorsza czynność } \\
\text { płuc, częste hospitalizacje }\end{array}$ \\
\hline $\begin{array}{l}\text { Osoby z objawami prowokowanymi } \\
\text { przez wysitek }\end{array}$ & $\begin{array}{l}\text { Wysiłek jest jednym z czynników prowokujących objawy astmy, ale też inne problemy zdrowotne } \\
\text { mogą być odpowiedzialne za duszność w czasie i po wysiłku }\end{array}$ \\
\hline Sportowcy & $\begin{array}{l}\text { Wysoka chorobowość astmy i prowokowanego przez wysiłek skurczu oskrzeli, słaba korelacja } \\
\text { objawów z wynikami badań czynnościowych płuc, częste infekcje i inne problemy }\end{array}$ \\
\hline Osoby z astmą zawodową & $\begin{array}{l}\text { Wszyscy, u których astma wystąiła w wieku dorosłym, powinni być badani pod kątem astmy } \\
\text { zawodowej, zwykle astmę zawodową poprzedza zawodowy nieżyt nosa }\end{array}$ \\
\hline $\begin{array}{l}\text { Chorzy przed planowym zabiegiem } \\
\text { operacyjnym }\end{array}$ & $\begin{array}{l}\text { Ryzyko okołooperacyjne zbliżone do populacji ogólnej z wyjątkiem osób ze znacznie obniżonymi } \\
\text { parametrami wentylacyjnymi, kluczowe jest osiągnięcie kontroli astmy przed zabiegiem }\end{array}$ \\
\hline $\begin{array}{l}\text { Chorzy z nadwrażliwością na aspi- } \\
\text { rynę i inne niesteroidowe leki prze- } \\
\text { ciwzapalne }\end{array}$ & $\begin{array}{l}\text { Prowokacje aspirynowe „złotym standardem” diagnostycznym, w przypadku konieczności podania } \\
\text { niesteroidowych leków zapalnych zalecane są selektywne inhibitory COX-2 i paracetamol pod nad- } \\
\text { zorem lekarskim, dodatkową opcją jest desensytyzacja }\end{array}$ \\
\hline $\begin{array}{l}\text { Chorzy z tzw. astmą trudną do lecze- } \\
\text { nia lub ciężą }\end{array}$ & $\begin{array}{l}\text { Zweryfikować rozpoznanie, sprawdzić i ewentualnie poprawić compliance oraz technikę inhalacji, } \\
\text { diagnozować i leczyć choroby wspóttowarzyszące, modyfikować czynniki ryzyka }\end{array}$ \\
\hline
\end{tabular}


Tabela 6. Definicja zaostrzeń astmy według raportu GINA 2014 [1]

\section{Table 6. Defintion of asthma exacerbation [1]}

Zaostrzenia to epizody charakteryzujące się nasilającymi się objawami duszności, kaszlu, świstów lub ucisku w klatce piersiowej, z postępującymi zaburzeniami czynności płuc, które są zmianą w stosunku do codziennego stanu pacjenta i wymagają modyfikacji leczenia
Tabela 7. Zespół nakładania astma/przewlekła obturacyjna choroba płuc (ACOS) [1]

Table 7. Asthma-COPD overlap syndrome (ACOS) [1]

ACOS to zespót charakteryzujący się utrwaloną obturacją dróg oddechowych oraz kilkoma cechami związanymi z astmą i kilkoma cechami związanymi z przewlekłą obturacyjną chorobą płuc. ACOS jest więc rozpoznawany za pomocą cech, które występują i w astmie, i przewlekłej obturacyjnej chorobie płuc

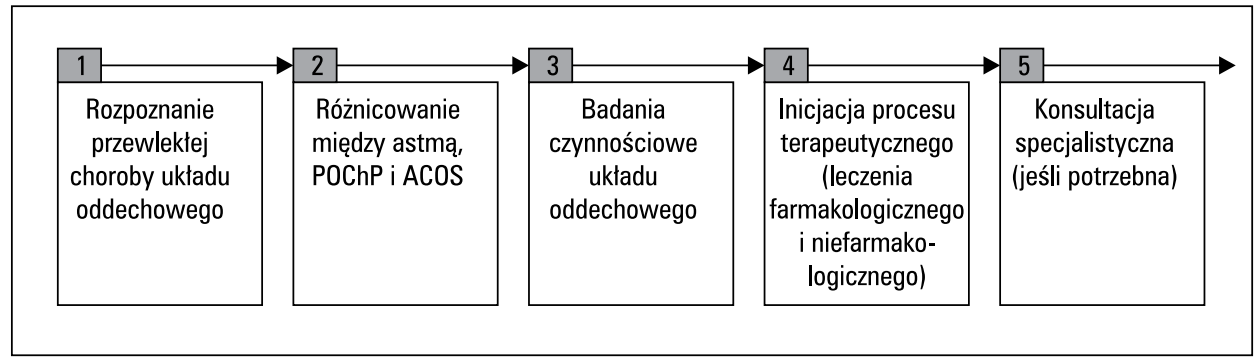

Rycina 4. Algorytm diagnostyczno-terapeutyczny w zespole nakładania astma/przewlekła obturacyjna choroba płuc według GINA 2014 [1]

Figure 4. Stepwise aproach to diagnosis and treatment of patients with asthma - COPD overlap syndrome accordint to GINA Report 2014 [1]

dotyczące leczenia. Eksperci uzasadniają wyróżnienie takiej grupy chorych z powodu częstych zaostrzeń, złej jakości życia, szybszego pogarszania się funkcji płuc, większej śmiertelności w tej grupie i wykorzystania zasobów ochrony zdrowia niż jest to obserwowane u pacjentów chorujących tylko na astmę lub POChP. Eksperci zdefiniowali ACOS jako zespół charakteryzujący się utrwaloną obturacją dróg oddechowych oraz kilkoma cechami związanymi z astmą i kilkoma cechami związanymi z POChP (tab. 7). Eksperci podają 5-stopniowy algorytm diagnostyczno-terapeutyczny (ryc. 4). Pierwszy stopień to rozpoznanie choroby przewlekłej układu oddechowego na podstawie objawów chorobowych, wywiadu narażenia na czynniki szkodliwe i wyników badań dodatkowych oraz odpowiedzi na uprzednio stosowane leczenie. Stopień drugi to różnicowanie astmy i POChP oraz ACOS na podstawie kluczowych cech z wywiadu, objawów klinicznych i badań dodatkowych (jeśli u chorego występują co najmniej 3 cechy astmy bez objawów POChP, to z dużym prawdopodobieństwem można rozpoznać astmę, tak samo jest w przypadku rozpoznania POChP, natomiast jeśli u tego samego pacjenta występuje podobna liczba cech obu chorób, można rozpoznać zespół nakładania). Trzeci - to wyniki badania spirometrycznego. Czwarty - propozycja postępowania terapeutycznego (farmakologicznego i niefarmakologicznego) w zależności od rozpoznania i stopnia pewności diagnozy. Piąty stopień zawiera wskazania do konsultacji specjalistycznej.

Różnicowanie astmy, POChP i ACOS na podstawie zaproponowanego przez ekspertów algorytmu jest skomplikowane i niepewne, bo choć algorytm diagnostyczny jest dość rozbudowany, to różne warianty odpowiedzi mają różną wartość predykcyjną. Zapewne w kolejnych latach zarówno definicja, jak i algorytm będą ulegały modyfikacji w kierunku uproszczenia i większej dokładności rozpoznania ACOS. Na uznanie zasługuje dostrzeżenie i próba rozwiązania tego, nie tak rzadko występującego w codziennej praktyce lekarskiej, problemu klinicznego.

Kolejną nowością jest dodanie obszernego rozdziału poświęconego astmie wczesnodziecięcej. Poprzednia taka publikacja z 2009 roku jest osobnym raportem poświęconym tej grupie wiekowej. W późniejszych raportach tylko fragmentarycznie odnoszono się do diagnostyki i leczenia dzieci do 5. roku życia. Eksperci podkreślają, że choć astma zwykle zaczyna się przed 5. rokiem życia, to decyzja czy obserwowane objawy u tak małych dzieci są już astmą jest szczególnie trudna. Nawracające świsty w tym wieku spowodowane są zwykle wirusowymi infekcjami górnych dróg oddechowych i dotyczą znacznego odsetka dzieci, ale nie zawsze są równoznaczne $\mathrm{z}$ rozpoznaniem astmy. Eksperci krytycznie odnoszą się do wcześniej opisywanych fenotypów świstów opartych na objawach i czasie występowania 
Tabela 8. Intensyfikacja leczenia u dzieci do 5. roku życia na podstawie rekomendacji ekspertów GINA 2014 [1]

Table 8. Stepwise approach to asthma treatment in children 5 years and younger according to GINA experts' recommendation [1]

\begin{tabular}{|c|c|c|c|c|}
\hline \multirow{2}{*}{$\begin{array}{l}\text { Stopień } \\
\text { terapii }\end{array}$} & \multicolumn{2}{|c|}{ Terapia kontrolująca } & \multirow[t]{2}{*}{ Leki ratunkowe } & \multirow[t]{2}{*}{ Inne zalecane metody interwencji } \\
\hline & preferowane & inne opcje & & \\
\hline 1 & Bez terapii & Bez terapii & \multirow[t]{4}{*}{ Doraźnie SABA } & \multirow{4}{*}{$\begin{array}{l}\text { Edukacja } \\
\text { Samokontrola } \\
\text { Indywidualny plan terapii } \\
\text { Niefarmakologiczne interwencje } \\
\text { Terapia chorób współtowarzyszących } \\
\text { i modyfikacja czynników ryzyka } \\
\text { Regularne kontrole lekarskie } \\
\text { Przed intensyfikacją: } \\
\text { Weryfikacja diagnozy } \\
\text { Kontrola stosowania się do zaleceń } \\
\text { Kontrola techniki inhalacji } \\
\text { Kontrola ekspozycji na alergeny } \\
\text { i zanieczyszczenia powietrza }\end{array}$} \\
\hline 2 & Niska dawka ICS & LTRA lub ICS we wstawkach & & \\
\hline 3 & $\begin{array}{l}\text { Podwojenie niskiej dawki } \\
\text { ICS (średnia) }\end{array}$ & Niska dawka ICS + LTRA & & \\
\hline 4 & $\begin{array}{l}\text { Kontynuuj leki kontrolują- } \\
\text { ce i skieruj do specjalisty } \\
\text { na konsultację }\end{array}$ & $\begin{array}{l}\text { Wzrost dawki i częstości dobowej } \\
\text { ICS } \\
\text { + LTRA (ew. teofilina, niską dawka } \\
\text { OCS [ostatni lek tylko na kilka tygo- } \\
\text { dni]) } \\
\text { + okresowo dodatkowa dawka ICS } \\
\text { do regularnej dobowej dawki ICS } \\
\text { u dzieci z zaostrzeniami }\end{array}$ & & \\
\hline
\end{tabular}

ICS (inhaled corticosteroids) — wziewne glikokortykosteroidy; LTRA (leukotriene receptor antagonists) — antagoniści receptora leukotrienów; SABA (short acting beta2-agonists) — krótkodziałające beta2-mimetyki

w kontekście stawiania rozpoznania w warunkach codziennej praktyki klinicznej. Zalecają w diagnostyce opieranie się na charakterystycznym obrazie klinicznym (świsty i kaszel, które prowokuje wysiłek i śmiech w czasie wolnych od infekcji), obecności czynników ryzyka (wywiad innych chorób alergicznych [atopowe zapalenie skóry lub alergiczny nieżyt nosa] lub astma w rodzinie w pierwszej linii pokrewieństwa) i odpowiedzi na leczenie (poprawa po 2, 3 miesiącach leczenia i pogorszenie po przerwaniu terapii). Do oceny ryzyka eksperci polecają Asthma Predictive Index (API). Jako że w tej grupie wiekowej rzadko udaje się przeprowadzić testy czynnościowe, szczególne znaczenie przed ostatecznym postawieniem diagnozy ma diagnostyka różnicowa, rozpoznanie astmy niesie $z$ sobą bowiem istotne długoterminowe konsekwencje.

Cele leczenia u małych dzieci są takie same jak u starszych dzieci i dorosłych osób: osiągnięcie kontroli choroby i utrzymanie normalnej aktywności życiowej oraz minimalizacja ryzyka zaostrzeń, upośledzenia funkcji płuc i objawów ubocznych stosowanego leczenia. Podstawowe zasady leczenia dzieci nie różnią się od ogólnie przyjętych, z wyjątkiem preferencji w leczeniu ICS, innych zalecanych dawek ICS, braku zaleceń do stosowania LABA, 4-stopniowej intensyfikacji leczenia (tab. 8), innych systemów podawania leków (aerozole pMDI [pressurised metered-dose inhaler] przez komorę inhalacyjną, alternatywnie nebulizacje).

Wiele uwagi w nowych wytycznych poświęcono leczeniu zaostrzeń u małych dzieci. Po- dobnie jak u pacjentów dorosłych, podkreśla się konieczność wczesnej interwencji już w domu. Eksperci jednak dość ostrożnie odnoszą się do samodzielnego stosowania przez rodziców doustnych lub wysokich dawek ICS ze względu na ryzyko działań niepożądanych, szczególnie gdy te leki są stosowane niewłaściwie i podkreślają konieczność indywidualizowania decyzji.

Osobny rozdział poświęcono pierwotnej prewencji astmy i dokonano krytycznego przeglądu aktualnych strategii. Eksperci podkreślają istnienie okresu życia („wrażliwego okna”) dla możliwej aktywnej interwencji w okresie życia płodowego i zaraz po urodzeniu dziecka. Zalecają unikanie narażenia na dym tytoniowy już w czasie ciąży i następnie w pierwszym roku po urodzeniu dziecka, zachęcają do porodu drogą naturalną, radzą karmienie naturalne ze względu na ogólne korzyści zdrowotne, i jeśli to możliwe, unikanie stosowania paracetamolu i antybiotyków o szerokim spektrum działania w pierwszym roku życia. Rekomendacji nie zyskała między innymi suplementacja witaminy D, probiotyki, modyfikacje diety czy interwencje zmniejszające narażenie na alergeny.

Ostatni rozdział poświęcono wdrożeniu wytycznych na poziomie ogólnoświatowym i lokalnym w celu poprawy jakości opieki nad chorymi na astmę i optymalizacji kosztów.

Nowe wytyczne są zwięzłym kompendium w odpowiedzi na zapotrzebowanie klinicystów na bardziej praktyczne, a nie naukowe podejście do problemu opieki nad chorym na przewlekłą astmę oskrzelową i nad dziećmi z grupy ryzyka. Są źródłem konkretnych prostych rozwiązań 
w wielu sytuacjach klinicznych, choć pozostają jeszcze zagadnienia, jak zespół nakładania, które zapewne w kolejnych wydaniach będą ulegały modyfikacjom w oparciu o doświadczenia płynące z codziennej praktyki klinicznej. Nowy raport zawiera wiele przejrzystych i prostych algorytmów przydatnych w pracy lekarza zarówno w podstawowej opiece zdrowotnej, jak i placówkach specjalistycznych. Wykorzystując wytyczne należy jednak pamiętać o konieczności indywidualizacji leczenia w zależności od możliwości i preferencji pacjenta oraz jego stanu ogólnego, w tym chorób współtowarzyszących, by zoptymalizować efekty terapii.

\section{Konflikt interesów}

Autorzy deklarują brak konfliktu interesów.

\section{Piśmiennictwo:}

1. Raport Global Strategy for Asthma Management and Prevention - Revised 2014 www.ginasthma.org

2. Chung K.F., Wenzel S.E., Brozek J.L. i wsp. International ERS/ ATS Guidelines on Definition, Evaluation and Treatment of Severe Asthma Eur. Respir. J. 2014; 43: 343-373. 